\title{
Disrupting the Discourse Behind the Zoning of the Native Americans: Linda Hogan's Mean Spirit in the Environmental Racist Perspective
}

\author{
Sehrish Bibi $^{1} \&$ Wajid Hussain ${ }^{2}$ \\ ${ }^{1}$ National University of Modern Languages (NUML), Islamabad, Pakistan \\ ${ }^{2}$ Faculty Social Sciences, Shaheed Zulfikar Ali Bhutto Institute of Science \& Technology (SZABIST), \\ Islamabad, Pakistan \\ Correspondence: Sehrish Bibi, National University of Modern Languages (NUML), Islamabad, Pakistan. E-mail: \\ sehrish_005@yahoo.com
}

Received: June 6, 2019 Accepted: July 2, 2019 Online Published: July 17, 2019

doi:10.5539/ijel.v9n4p358 URL: https://doi.org/10.5539/ijel.v9n4p358

\begin{abstract}
This paper disrupts the Euro Americans' environmental colonialist discourse which involves the practices of racist policies that result in the relocation of the Native Americans to a confinement called reservation. More specifically, it discusses this relocation which is termed as zoning as a dilemma for the Natives because this practice by the Euro Americans, which primarily involves their economic agenda, not only restricts the Natives to their reservation and denies life opportunities for them but puts the responsibility of their plight on themselves. A qualitative content analysis, the research explores this idea in Linda Hogan's Mean Spirit in the light of the joint critique of environmental racism and critical discourse analysis. Linguistically, the study applies critical discourse analysis focusing on van Dijk's concept of discourse and manipulation. The analysis reveals that the discursive and cognitive strategies employed by the Euro Americans for the zoning of the Natives help the former rationalize and legitimize their environmental colonial practices. The discursive process first involves the creation of "othering" and then the tactful presentation of this "othering". The study also highlights the counter actions taken by the Natives on the basis of the same strategies as have been employed against them, to resist their zoning.
\end{abstract}

Keywords: racism, environment, zoning, critical discourse analysis

\section{Introduction}

In today's world, the American economic engine has generated massive wealth due to rapid growth of industrialization and resultantly given birth to a large number of environmental destruction agents. The resultant economic superiority pushed the pollutants to the land of natives on periphery which left the natives with a little access to services, goods and opportunities of life. Moreover, the Native as a marginalized group have been exposed to toxic waste, industrial pollutants, pollutants of natural resource extraction and landfills. This exposure of the natives to toxic waste and pollution is an aspect of environmental racism, which Robert Bullard (2001) defines as a geographic injustice in which non-whites are disproportionately burdened by various forms of pollution and hazards. Bullard finds a direct relationship between the exploitation of land and exploitation of people.

Moreover, the environmental racist polices have legitimized the restriction of the Natives to the confinements called as "zones" or "reservations". The process is termed as "zoning" which is a prevalent form of land-use control and which has restricted the Natives' mobility as well. Zoning, which has resulted from the Euro American's projects, such as oil extraction, dam construction, mining etc. that, according to Winant (1994) serve as, "an interpretation, representation, or explanation of racial dynamics and effort to organize and distribute resources along particular racial lines" (24), transfers the burden of pollution to the natives. These zones of the natives are further exploited for natural resources. The process establishes for the Euro Americans an "othering" about the Natives, which invents a dominant discourse for its ideological foundation. This dominant discourse with its cognitive function serves as the primary mechanism for the Euro Americans' environmental agenda, as Luckett (2004, p. 512) says that the perception of environment is purely based on human thinking "which is outside the system". According to Foucault (1972), discourse is a highly regulated form of communication, which, in spite of offering an unlimited potentiality for meanings, entirely depends upon socio-cultural ideologies. He says that 
it is these ideologies which regulate the expression which linguistic symbols merely mediate.

This point is reinforced and further explained by critical discourse analysts who link the element of power with language. Van Dijk (2006) emphasizes on the cognitive element in this process of meaning making. According to him, the processes through which discourse influences mind, which itself involves highly complex process, are very intricate and "can only be managed in real time by applying efficient strategies" (Van Dijk, 2006, p. 365).

The study seeks to explore the discursive and cognitive strategies behind the zoning of the Native Americans by the powerful Euro American group as reflected in Linda Hogan's Mean Spirit. In this connection, it deconstructs the powerful discourse along with its social resources which helps the powerful group to legitimize this relocation and confinement of the natives to the reservation by first creating an "othering" about them and then, on the basis of this "othering" holding them responsible for the environmental devastation as well. The study exposes this agenda through the perspective of critical discourse analysis focusing on van Dijk's concept of discourse and manipulation.

\subsection{Research Objectives}

This paper aims at meeting the following research objectives by analyzing Linda Hogan's Mean Spirit in the light of the concepts of ecocriticism and critical discourse analysis: to ascertain the extent to which the discourse of the Euro Americans legitimizes the zoning of the natives; and to investigate how the natives realize and attempt to counter their manipulation at the hands of the Euro Americans.

\subsection{Research Questions}

1.2.1 To what extent does the discourse of the Euro Americans legitimize their policies about the zoning of the natives as reflected in Linda Hogan's Mean Spirit?

1.2.2 How do the natives realize and try to counter their manipulation by the Euro Americans, which occurs on the basis of the discourse strategies by the latter?

\subsection{Zoning as an Environmental Racist Tactic}

Environmental racism primarily rests on the tactful discourse of the manipulative group, which legitimizes the discrimination in unjustifiable issues. This discourse is formed by the environmental policies which affects the quality of environment. Bullard and Johnson (2000) put this racist discourse in the following words, "Any environmental policy, practice or directive that differentially affects or disadvantages individuals, groups or communities based on race or color". According to them, this environmental racist discourse "combines with public policy and industry practices to provide benefits for whites while shifting costs to people of color" (Bullard \& Johnson, pp. 559-560).

Benjamin Chavis (Reference) termed environmental racism as "racial discrimination" in "environmental policy making" in which policy-makers deliberately target people of color to life threatening presence of poisons and pollutants. Factors that are responsible for environmental inequality are states' action and political powers. Turner and Pei $\mathrm{Wu}(2002)$ mentions these factors as capitalism, policies and regulations along with social stratification based on race, ethnicity and class-interact with the strategic actions of multiple actors, communities, and regulators. Such policies target people of inferior race, ethnicity and class as a result of "unjust" environmental actions. As a result of unjust environmental policies, the indigenous people are pushed into the confinements called zones to live within the fixed boundaries of these polluted "reservations". In addition, these zones are constantly exploited by Euro Americans through intrusions for natural resources. Bullard mentions that environmental policies "limit mobility, reduce neighborhood options, diminish job opportunities, and decrease choices for millions of Americans (102)".

Through the zoning laws the government of the United States deprives the natives of their right of land use. Douglas Massey and Nancy Denton (1993) argue that segregation occurs due to "impersonal market forces" and various other socio-economic processes. The zoning decisions show the power of the government to maintain "the residential colour line" from nineteenth century up to present. Logan (1987) writes about environmental inequality of low-income society. They are subjected to polluted environment and are not able to protect their environmental interests. Jonathan Rothwell links zoning directly with "racial segregation". Bradely Angel (1991) raises his voice against the exploitation of the Native Americans and their land. On the reservations, a new method of assault is designed in the form of "economic development". This practice turns the natives' lands into poisonous grounds, as Angel describes: "the waste disposal industry and the U.S. government have embarked on an all-out effort to site incinerators, landfills, nuclear waste storage facilities and similar polluting industries on Tribal land" (Angel, 1991, p. 1). 
The displacement of the Native Americans, which leads to various socio-economic impacts, is technically rooted in discourse which is, at macro level, for example, manifested in the notion of "othering" which is exploited ideologically. Homi K. Bhaba (2004), for example, explains this tactic in connection with the concept of displacement. He writes that “'Beyond' signifies spatial distance, marks progress, promises the future, but our intimations of exceeding the barrier or boundary - the very act of going beyond - are unknowable, unpresentable, without a return to 'present' - which, in the process of repetition, become disjunct and displaced" (p. 4). He writes about post-colonial migration and terms it as poetics of exile. He writes that "a boundary is a pace from where something begins its presenting in a movement no dissimilar to ambulant" (p. 5). To him, the condition of unhomeliness is extraterritorial with a confused vision. Displacement leads to traumatic personal and psychic history.

The current study aims at exposing these discursive strategies of the powerful group which help it to legitimize the displacement of the natives. For this, the study applies the perspective of Critical Discourse Analysis which aims at exposing the agenda behind the powerful discourse.

\subsection{Critical Discourse Analysis}

Critical discourse analysis exposes the latent agenda behind the discourse of the dominant social group. It brings to the limelight the power relation behind the language which may be manifested in text or talk. First, it believes that it is discourse which determines the social knowledge and power structure, as Foucault says that it is discourse which establishes relevant truth and that every regime has that knowledge and truth which is shaped by its discourse. Similarly, Locke (2004) also finds discourse as always dependent on social context. To him, it is "way of constructing the process of meaning-making in society" (Locke 2004, p. 6). Faircough (1992, p. 12) also refers to the same idea through his concept of naturalization which is a discourse process that leads towards a common ideology which establishes the worldview for the masses within which they try to find out the truth. The current research builds up its stance on the same notation as it aims to deconstruct the discourse involving the environmental policies of the powerful group which aim to discriminate the natives to the extent of displacing and confining them to the reservation.

However, the current research concerns more with the macro features of discourse, which means that it involves ideological aspects; so, it specifically focuses on the cognitive and discursive links with the established 'truth' and, with reference to this, concentrates upon van Dijk's concept of discourse-cognition-society.

\subsubsection{Discourse and Manipulation}

Van Dijk (2006) puts emphasis on the cognitive aspect, which according to him, plays fundamental role in the process of meaning making in society. He suggests that the processes involving discourse are very complex and "can only be managed in real time by applying efficient strategies" (Van Dijk, 2006, p. 365). He opines that the powerful social group uses discourse for manipulation in order to achieve dominance over the weaker groups and this manipulation is cognitive in nature. Though he does not undervalue the micro features of discourse such as grammatical, semantic, pragmatic, rhetorical, verbal, paraverbal etc., his focus majorly remains on cognitive aspect of discourse. He says (as cited in Meyer \& Wodak, 2009, p. 66), a social context is primarily a cognitive representation and that it is a subjective and dynamic online model which guides the participants about the relative properties of the communicative situation.

Additionally, mental models, according to him, not merely share knowledge but enforce it as well (van Dijk, 1997, p. 189). This happens because social knowledge and beliefs determine an individual's discourse. Van Dijk (1997) thinks that models are richer in producing and understanding information than discourses that are based on these models (van Dijk, 1997, p. 198). For example, a journalist will include only that detail in their report which suits them ideologically. Choices are, therefore, regulated in accordance with the context model. Such context-sensitive strategies also include relevance and irrelevance, completeness, specification and generalisation, self and other presentation etc. The use of the pronouns, such as us and them, is one of the major tactics to highlight self and other presentation, for van Dijk (1997) writes, "Self- and other-representation in context models, and the display of such identities and allegiances in talk, usually also show in the choice of pronouns" (van Dijk, 1997, p. 217). Other common semantic strategies include: emphasizing preferred meanings and de-emphasizing unwanted ones; (de)-topicalizing; making expressions explicit or implicit and clear or vague accordingly; and focusing on rhetorical devices.

He says that through these semantic strategies discourse aims to control the shared social representations of groups of individuals because it is these social representations or values which control the talks and actions of people (van Dijk, 2006, p. 365). Therefore, after people's attitudes are influenced, further efforts for manipulation are seldom required for the achievement of the desired results. 


\section{Methodology}

The study is qualitative in nature and applies textual analysis technique. Moreover, it establishes its theoretical framework with the concept of environmental racism and analyses the selected text that is Linda Hogan's Mean Spirit under the perspective of critical discourse analysis focusing on van Dijk's notion of Discourse and Manipulation. These two perspectives have been aligned for the textual analysis under the concept of theoretical triangulation. Theoretical triangulation offers manifold views to analyse a research question (Patton, 2002, p. 453). It may provide inconsistencies; however, it, according to Patton, does offer an opportunity to explore deeper understanding of the data. The research also follows Van Dijk's concept of Discourse and Manipulation as a model. In this connection, it focuses on the following aspects: cognitive manipulation; positive self-presentation and negative other-presentation; macro speech act implying our 'good' acts and their 'bad' acts, e.g., accusation, defence; giving many/few details; being general/specific etc.; lexicon: selecting positive words for us and negative words for them.

\section{Discussion}

\subsection{Cognitive Manipulation}

According to van Dijk, the role of the micro features of discourse lies in the fact that they intermediate between the cognition of the individual and the events concerned. So, these micro discourse features form the worldview of the dominated so that when they think, behave and act, they think, behave and act in the best interests of the manipulator. In the context of the study, the cognition of the individual is manipulated through the legal rhetoric. First, the legal source is itself a scarce social source which is monopolized by the powerful group. Now, this powerful discourse is helping the rise of the economy of the powerful group through industry and discriminating and exploiting of living places of the Native Americans. Thirdly, and more importantly, it is creating ecological disturbance as well. The U.S. government took every possible benefit from reservation land. They find oil in Osage Territory and set up their industry to extract oil and offer the Indians with a minimum part of oil money. The power discourse which gets stronger with the changing social conditions, increasingly changes the worldview for the Natives. This happens, for example, through the commodities introduced by the powerful group for the purpose of selling. These commodities include, for example, "beaver hats", "cameras", "Satin ribbon", "leather shoes", "jeweled watches", "razor blades", "liquor", "skillets", "tortoise shell hair combs", "electric fan" and "gas stove". All these Euro American products are establishing the natives' outlook accordingly. Hogan mentions that "It was hard for the newly rich Indians to take their wealth seriously and most were more than happy to buy any and all of the gadgets [white retailers sold them for high price]" (p. 57).

\subsection{Self and Other Presentation}

The presentation of positive self and negative others is also one of the primary discourse strategies employed by the manipulator. This tactic aims at justifying the actions of the manipulator as against those of the manipulated by promoting a pleasant image of the former and an adverse impression of the latter. In the context of the study, the natives are, in the first instance, relocated to the reservation which becomes place for the disposal of uranium and other waste. Then, these Indians are tagged with the pollution and the disorder that results from heaps of the waste. So, ultimately the reservation and the natives become one and the same thing. The presentation of the natives and that of the Euro Americans, therefore, become binary oppositions, each getting its recognition from the other.

However, the Euro Americans show flexibility for the intermingling of the two extremes when it comes to suit their agenda. For example, Will Forrest, who belongs to the powerful Euro American group, marries Nola Blanket, an Osage. Moreover, Will's parents are Nola's legal guardian and Nola is the richest oil woman after the death of her mother, Grace Blanket. Will is encouraged for this marriage by his father who tells him that his new wife "is your paycheck". Now, "she is the one who pays for your good suits and hats" (p. 191).

The readjustment needs reconsideration in representation as well. Will is advised by his people to justify his money which has come to him through his wife by donating a part of it for some social welfare. His driver suggests him to launch a memorial hospital with his name and "They'd all forget where your money came from" (193). So, white men start charity work like the construction of hospital with the oil money of their Osage wives. These charity works are used as a tactic to manipulate the minds of natives about their earnings.

This presentation of positive self and negative others is frequently reflected in Hogan's writings. She says “white people rarely concerned themselves with Indian matters, that Indians were the shadow people, living almost invisibly on the fringes around them, and that this shadowy world allowed for strange kind of freedom" (p. 81). Once this presentation is accordingly established, the Euro American can legitimize their environmental racist policies and implement them. 
Similarly, this tactic of self and other presentation is reflected in the way the powerful Euro Americans justify the deaths of the natives for which the former are themselves responsible. Grace Blanket is shot and her sister Sara burned in her house. Stink is murdered mysteriously while Baniot is hanged in jail. In the same way, Walker died of alcohol poisoning and Palmer is shot in his store. Levee, who is a white investigator, presents these deaths in the following words, "There is oil, lots of it, and all belonging to Indians" (2). That is why, "Most of the victims are Indians" (p. 52).

\subsection{Being General/Specific; Vague/Clear}

Similar to the strategy of self and other representation, this strategy generalizes specific events and specifies the general. In the context of the study, the Euro Americans have formed general economic policies which are already interests oriented. But, whenever they find any conflict of interest in these policies, they amend them for the specific event accordingly. For example, they initially promised the Osages for an equal share of total mineral income but when the latter, such as Moses Greycloud, visit to collect their annual payment, they at once "changed the regulation" (Hogan, p. 60). "Full-blood only gets part of their money. You're getting ten per cent today" (pp. 60-61). Moses Greycloud can register a humble complaint, "in the spring you told us our people with the white blood only received part of their money since they are part white. In addition, not entitled. Now you are saying that we full bloods get only part of our money" (p. 61).

\subsection{Our Good Acts and Their Bad Acts/Self-Defence Other Accusation}

This strategy, which highlights our acts as good and their acts as bad and which is done for self-defence by accusing others, helps the powerful group to rationalize their actions further. Horse's payment is his only source of income. His land is barren, so he is unable to take its advantage. Reduction in his payment leads him to miserable condition as he is unable to support his family now. He remains silent because he knows that if he says a single word to the authorities to increase his money, he would be declared insane by them. "The courts had already named at least twenty competent Indian people as incompetents, and had already withheld all their money until they were assigned legal guardians" (p. 62).

Then, the government also employs the tactic to declare the Osages as incompetent in order to appoint white attorneys for them who act as their guardians. The purpose is to give the white the right to own the money of these Osages. Stace Red Hawk observes, "Even a prophet, even a warrior, could not survive the ways of Americans, especially the government with rules and words that kept human life at a distance and made it live by their regulations and books" (p. 221).

Mean Spirit also reflects this practice of self-defence and accusing others which is supported through the tactic of presenting the details as vague or clear and general or specific accordingly. For example, after the murder of Grace Blanket, Osages are well aware of the fact that the authorities will not reveal the secret. Natives also remain silent for their own safety. Beniot is called for investigation but he does not utter a word about black Buick as he sensed danger to his own life. He suspects that the white authorities knew about the owner of the car, but they are pretending. Baniot knows that if he will give any clue about the murderer he will be killed by the authorities. He stays in prison without any reason. He is suffering in jail guiltlessly. Lettie is worried about his painful situation when she says; "I can't stand it! My God. He has not even been charged and they say he is guilty." (p. 145)

Baniot's case has no legal proceedings. "They had not yet brought him to trail. Federal court did not want to try the case, though they claimed that Indian country was federal jurisdiction. Country court couldn't try Benoit even though they held the young man in country jail" (p. 191). Finally, the white authorities murder him and his death is presented to people as a simple suicide case.

Similarly, the novel also offers instances where the practice of self-defence and accusing others are manifested through the discourse tactic of self and other presentation. Hogan's Mean Spirit is based on the real murder of the twenty-five years old Anna Brown, the richest Osage woman. On her dead body whisky was sprinkled with a gunshot in her head. The dead body is presented to show that it was as a suicide case. Later on, her sister's family is also killed in their house that was burned with fire. Their death appears as an accident. Grace Blanket is the richest Osage women in the territory. She is killed in the beginning of the novel under similar circumstances. Similarly, Sara who is Grace's sister also died in house that had burnt to ashes.

The responsibility of all these murders in the Osage territory lies on William K. Hale. His fictional counterpart is John Hale. The man has built up wealth and influence on the reservation. The Natives respect him because of his friendliness and award him with the title of King of Osage Hills. He lives among the Osages whom he hires to "help him cut, burn, and clear their own land" and the Osages also "knew and trusted him" (p. 54). He came to the Indian territory with cattle business, but secretly he wants to seek his fortune in black oil. Through friendly nature 
he wins the trust of the Osages. He takes advantage of those who are in debt and sell their few more acres to Hale. Hale is aware of the hidden money of the land so he is always ready with "quick offer and fast cash" (p. 54). He also uses another way to get the wealth of the Osages. This way is the lie insurance policy. Through this policy, he tactfully takes hold of the money and the land of the Osages after their death. More than a dozen murders were committed to take control of allotments and for insurance. Osages are out of their place and are used by the Euro American business people for their hidden agendas.

\subsection{Realization of Manipulation}

Critical discourse analysis exposes the power abuse and in doing so it takes stance in favour of the weaker. This means it offers solution as well. For this, it aims at bringing the dominated to the realization of their manipulation by the powerful group. This realization occurs through the acquisition of due knowledge that the dominated lacked earlier. Once the dominated come to achieve this knowledge, they resist the status quo. Moreover, they counter their domination through same or similar discourse strategies. They may, and do, try to access the social resources which have been monopolized by the powerful group. For example, the indigenous people write letters, which is a social resource, to the government for justice and protection of their land. Earlier, Linda Hogan has given the example of the same social resource which was used by the whites. Through a white man's letter, which is aimed for marriage proposal and which says, "If you can place me in correspondence with a good woman and I succeed in marrying her for every Five Thousand Dollars she is worth I will give you Twenty-Five Dollars. If she is worth 25,000 you would get $\$ 125$ if I got her" (p. 34), she exposes the fact that such marriages are meant merely for the acquisition of land and money. She reveals that marrying the Osage women is a sort of employment for the white men. "Another white man, when asked what he did for a living, said by way of an answer that he'd married an Osage woman, and everyone who listened understood what that meant, he lived off her money" (p. 34).

\section{Conclusion}

Linda Hogan's Mean Spirit reveals the Euro American's environmental colonialism which is reflected in their discourse structure that involves the practices of racist policies resulting in the relocation of the Native Americans. This powerful discourse along with its social resources helps the powerful group to legitimize this relocation and confinement of the Natives to the reservation by first creating an "othering" about them and then, on the basis of this "othering", holding them responsible for the environmental devastation itself.

The study, therefore, focused on micro features of discourse which involve ideological discussion which is processed and accomplished through the involvement of the cognition of the individual and the events concerned as the concept of the "othering" reflects this process as well. The analysis shows that the cognition of the individual is manipulated through the legal rhetoric. This legal source, which is a scarce social source monopolized by the powerful group, supports and builds their discourse to strengthen their economy which is majorly based on their increasing industry which threatens the lives of the Native Americans. In this connection, the study reveals that the introduction of the new commodities by the Euro Americans, such as "beaver hats", "cameras", "Satin ribbon", "leather shoes", "jeweled watches", "razor blades", "liquor", "skillets", "tortoise shell hair combs", "electric fan" and "gas stove" has established a discourse which has increasingly changed the worldview for the Natives.

In connection with the discourse strategies as employed by the powerful group for its economic agenda that results in the zoning of the Natives, the study also highlighted the strategy of positive 'self' and negative 'other' presentation. This strategy helps the manipulator in justifying the relocation of the Natives by promoting a pleasant image of themselves and an adverse impression of the others. Through this self and other presentation, the Natives and their reservation become one and the same thing.

Through this discourse strategy of self and other presentation, Linda Hogan also highlights the Euro Americans' practice of self-defence and accusing others. She does so also by deconstructing the powerful group's tactic of presenting the details as vague and clear and general and specific accordingly. Benoit is murdered but presented to his people as a case of suicide. Similarly, Anna Brown's murder is also declared a suicide, whereas the deaths of her sister's family appear an accident.

Finally, the study also revealed the way the Natives counter their manipulation by the Euro Americans through the similar strategies which had been employed against them. The Natives counter their domination, for example, by accessing the social resources which have been monopolized by the powerful group. The indigenous people write letters to the government for justice and protection of their land. Earlier, Linda Hogan has given the example of the same social resource which was used by the whites. She has informed us about a letter, which aims at conveying the proposal for a marriage which is aimed merely for monetary purpose. 


\section{References}

Adamson, J. (2001). American Indian Literature, Environmental Justice, and Ecocriticism. Tucson: The University of Arizona Press. Web.

Ashcroft, B., Gareth, G., \& Helen, T. (1998). Key Concepts in Post-Colonial Studies. London: Routledge. Web.

Belsey, C. (2005). Textual Analysis as a Research Method (Gabriece, Ed.).

Blaeser, K. (1999). Centering Words: Writing a Sense of Place. Emergent Ideas in Native American Studies, 14(2), 92-108. https://doi.org/10.2307/1409554

Bullard, R. D. (1991). Dumping in Dixie: Race, Class, and Environmental Quality. Social Forces, 70(1), 270271. https://doi.org/10.2307/2580094

Bullard, R. D. (1993). Unequal Protection: Environmental Justice and Communities of Color. San Francisco: Sierra Club books. Web.

Bullard, R. D. (1993a). The Threat of Environmental Racism: Natural Resources and Environment. Electronic Green Journal, 1(1).

Bullard, R. D. (1994). Unequal Protection: Environmental Justice and Communities of Color. SAGE Journals, 15(4).

Bullard, R. D. (1999). Dismantling Environmental Racism in the United States of America. The International Journal of Justice and Sustainability, 4(1), 5-19. https://doi.org/10.1080/13549839908725577

Bullard, R. D. (2001). Confronting Environmental Racism in 21st Century: Voices from the Grassroots. The Phylon Quarterly, 49(3), 151-171. https://doi.org/10.2307/3132626

Bullard, R. D., \& Glenn S. J. (2000). Environmental Justice: Grassroots Activism and its Impact on Public Policy Decision Making. Journal of Social Issues, 56(3), 555-578. https://doi.org/10.1111/0022-4537.00184

Chavis, B., \& Charles L. (1987). Toxic Waste and Race in the United States. USA: United Church of Christ Commission for Racial Justice. Retrieved August, 2014, from https://www.nrc.gov/docs/ML1310/ML13109A339.pdf

Cohen, F. S. (2005). Handbook of Federal Indian Law. Web.

Cole, L. W., \& Sheila R. F. (2001). From the Ground Up: Environmental Racism and the Rise of Environmental Justice Movement. New York and London: New York University Press. Print.

Cutter, S. L. (1995). Race, Class and Environmental Justice. Progress in Human Geography, 19(1), 111-122. https://doi.org/10.1177/030913259501900111

Deloria, Jr., \& Vineand C. M. L. (1984). American Indians, American Justice. Austin: University of Texas Press. Print.

Fairclough, N. (1995). Critical Discourse Analysis. London: Longman.

Foucault, M. (1972). The Archeology of Knowledge. London: Tavistock Publications.

Glotfelty, C., \& Harold, F. (1996). The Ecocriticism Reader: Landmarks in Literary Ecology. Athens and London: University of Georgia. Web.

Hogan, L. (1990). Mean Spirit. New York: Ivy. Print

Huggan, G., \& Helen T. (2010). Post-Colonial Ecocriticism: Literature, Animals and Environment. New York: Routledge. Print. https://doi.org/10.4324/9780203498170

Iverson, P. (1998). We are Still Here: American Indians in the Twentieth Century. Harlon Davidson, Inc. Print.

Locke, T. (2004). Critical Discourse Analysis. London, New York: Continuum International Publishing Group.

Logan. (1987). Urban Fortunes: The Political Economy of Place. University of California Press. Web.

Massey, D., \& Nancy. (1998). American Apartheid: Segregation and Making of the Underclass. Web.

McAuliffe, D. A. (1994). Bloodland: A Family Story of Oil, Greed, and Murder on the Osage Reservation. San Francisco: Council Oak. Web.

Meyer, M., \& Wodak, R. (2009). Methods of Critical Discourse Analysis (Introducing Qualitative Methods Series, p. 66). London: Sage.

Patton, M. (2002). Qualitative Research and Evaluation Methods. Thousand Oaks, CA: Sage. 
Rothwell, J. T. (2011). The Effects of Racial Segregation on Trust and Volunteering in US Cities. Urban Studies, 49(10), 2109-2136. https://doi.org/10.1177/0042098011428180

Said, E. (2000). Reflections on Exile. Cambridge and Massachusetts: Harward University Press. Web.

Turner, R. L., \& Diana P. W. (2002). Environmental justice and Environmental Racism: An Annotated Bibliography and General Overview, Focusing on U.S Literature, 1996-2002. Berkeley: University of California. Print.

van Dijk, T. A. (1978). Orientalism. New York: Vintage. Web.

van Dijk, T. A. (1992). Question of Palestine. Vintage. Web.

van Dijk, T. A. (1997). Cognitive Context Models and Discourse. Language Structure, Discourse and the Access to Consciousness, 190. https://doi.org/10.1075/aicr.12.09dij

van Dijk, T. A. (2006). Discourse and Manipulation. Discourse \& Society, 17(2), 359-383. https://doi.org/10.1177/0957926506060250

Wilson, T. P. (1985). The Underground Reservation: Osage Oil. Lincoln: Nebraska UP. Web.

Winant, H. (1994). Racial Conditions: Politics, Theory and Comparisons. Minneapolis: University of Minnesota Press. Web. https://doi.org/10.5749/j.ctttss2b

\section{Copyrights}

Copyright for this article is retained by the author, with first publication rights granted to the journal.

This is an open-access article distributed under the terms and conditions of the Creative Commons Attribution license (http://creativecommons.org/licenses/by/4.0/). 